\title{
Building energy performance optimization towards net zero energy building using passive solution technologies and building information modeling at design phase
}

\author{
Jewel Rana*iD, Mizanoor Rahman iD \\ Khulna University of Engineering \& Technology, Department of Building Engineering and Construction \\ Management, Khulna, Dhaka, Bangladesh
}

\begin{abstract}
Excessive amount of energy consumption confronts the world to great dangers such as global warming and climate change. About $40 \%$ of total energy consumption from conventional sources can be reduced to zero by taking appropriate decision at design phase for developing Net Zero Energy Building (NZEB). Two most important elements of NZEB are passive solution technologies for building energy efficiency and on-site renewable energy production for essential services. Passive solution technologies have much potentiality for reducing energy consumption and are made of unique architectural design considerations and special types of materials which have some unique characteristics. This study evaluated some passive solution technologies through rigorous energy simulation perspective using Autodesk Green Building Studio (GBS) and Autodesk Insight 360 . About 61 scenarios were made by using passive solution technologies and were assessed by Building Information Modeling (BIM) tool such as GBS through whole building energy simulation. Among them light-weight concrete as building envelope and foil faced glass fiber as building thermal insulation exhibited the best energy efficiency. Estimated renewable energy production potentiality of BIPV (Building Integrated Photo Voltaic) system of the prototype residential building was $122800 \mathrm{kWh}$ annually.
\end{abstract}

\section{Keywords}

Passive solutions; Building envelope; Thermal insulation; Building orientation; BIM; BIPV; NZEB

Received: 21 January 2020; Accepted: 13 March 2020

ISSN: 2630-5771 (online) @ 2020 Golden Light Publishing All rights reserved.

\section{Introduction}

Global warming is very alarming phenomenon in recent time. World climate is changing day by day due to excessive amount of CO2 emission. Most of the $\mathrm{CO} 2$ emission is caused by consuming energy for transport, industrial, residential and commercial building purposes. Energy comes from burning of fossil fuel that produces a huge amount of $\mathrm{CO} 2$. Fig. 1 represents the demand for electricity and the demand is increasing day by day. Electricity consumption in the commercial building sector doubled between 1980 and 2000, and is expected to increase another $50 \%$ by 2025 (EIA 2005) [1]. This huge amount energy consumption can be reduced to zero by developing NZEB. This study focused on residential projects to make a Net Zero Energy Building (NZEB) by incorporating passive solution technologies and renewable energy at design phase.

\footnotetext{
* Corresponding author

Email: jewelbecm2k13@gmail.com
} 


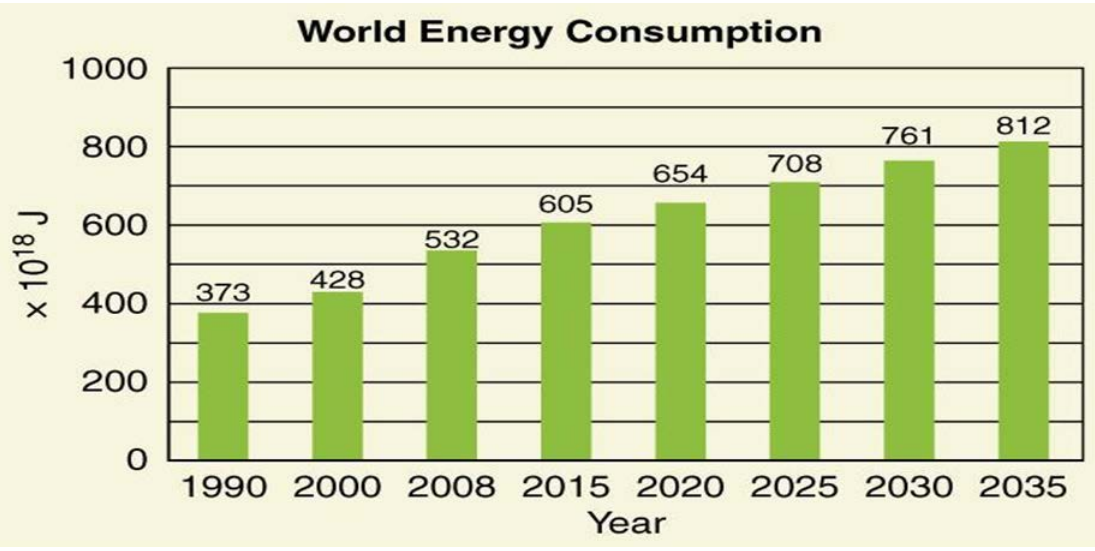

Fig. 1. Past and projected world energy use (source: Based on data from U.S. Energy Information Administration, 2011)

There is no actual definition of Net Zero Energy Building (NZEB) that can bear its whole concept. NZEB is a concept that means a building produces renewable energy from its own building footprint as much as it requires to consume [2]. It is a concept that a building can meet all their energy requirements from low-cost, locally available, nonpolluting, renewable sources[3]. The main framework of this building concept is based on the idea of an energy-producing and low-energy building that interacts with the energy infrastructure [4]. It requires to fulfill two main steps for designing NZEB such as developing an energy efficient building by incorporating passive solution technologies and providing renewable energy system in building footprint or site. An energy efficient building requires less energy demand than conventional building for running all facilities and on-site renewable energy sources can fulfill that demand of energy [5]. Passive solution technologies can help to achieve energy efficiency goal of a building. Passive house solution technologies are some special building design considerations which can help to reduce energy consumptions. For above reason, in design phase evaluating passive technology is very important. The aim of passive concept is to provide an acceptable and even improved indoor environment in terms of Indoor Air Quality (IAQ) and thermal comfort at minimum energy demand and cost [6]. Passive techniques can achieve energy efficiencies through effective building envelope, thermal insulation, natural ventilation, orientation, window wall ratio and shading devices etc. This study investigated the two most important passive technologies such as efficient building envelope and orientation. Proper use of thermal insulation and high energy efficient windows on building envelope can optimize energy consumption and improve thermal comfort [7]. According to study of five low energy buildings by Cheung [8], it was showed that there was a great impact of envelope design techniques on energy efficiency and he suggested some passive strategies like color of external wall, wall insulation, glazing types, windows sizes and shading devices. After implementing these strategies, around $40 \%$ cooling energy was saved by Cheung yearly. Beside another study was conducted in Hong Kong where 31.4\% of annual cooling energy was saved by adopting modern building envelope design strategies [9]. In a the study of Sozer [10], he incorporated a versatile passive technologies into a proposed building and it consumed $40.1 \%$ less amount of energy compared to baseline energy consumption of buildings in Turkey. According to Kumar [11], after adopting energy conscious building design, Energy Performance Index(EPI) in India vacillated to 100 to $150 \mathrm{kWh} / \mathrm{square}$ meter/ year which was previously 200 to $400 \mathrm{kWh} / \mathrm{square}$ meter/ year for commercial building. Building orientation is another efficient passive technology for reducing energy consumption. Morrissey [12] argued that in case of passive solar gain, orientation is one of the 
key elements. Xu replaced $60 \%$ to $80 \%$ artificial lighting to natural day lighting by properly orienting the studied building in China [13]. Abanda [14] saved around $£ 878$ in UK through the life cycle period by orienting the building to south. According to Al-Tamimi [15], if unventilated room is oriented in north direction it would be realistic to conquer a $16 \%$ of upgrading in the indoor thermal hours per year compared to the base orientation to south-west and in Malaysia. From above description, authors were capable of reducing energy consumption and cost using different passive solution technologies within various regions. This study finds the energy efficient passive building technologies for the residential building of Bangladesh. Making energy efficient building is not enough for NZEB designing, it still requires renewable energy to run all facilities. The potentiality of generating energy by renewable energy systems are dependent on some factors like building site, weather, shape \& orientation [16]. There are several types of renewable energy system that can be applied to the building footprint and also to the building site like Photo Voltaic (PV) system, Geo-thermal energy, Bio-gas plant and Wind turbine energy system. Main concern of this study is to develop a feasible and cost effective pattern of passive solution technologies and on-site renewable energy system to design a Net Zero Energy Building (NZEB) so that it will help to optimize the life cycle cost and annual energy consumption. The main objectives of this study are:

1. To find out the most energy efficient building envelope materials and orientation of a prototype residential building model for developing NZEB using BIM tools at design phase in the weather context of Bangladesh.

2. To estimate with the help of BIM the potentiality of generating PV energy after installing Building Integrated Photovoltaic (BIPV) system on roof and window of prototype residential building at design phase for developing NZEB in the context of Bangladesh.

\section{Energy efficient building envelope and insulation materials}

Buildings are mostly built for living in a confined space within a thermal comfort level. Air conditioning system is required for ensuring thermal comfort and consumes a lot of energy. It is estimated that about $50-70 \%$ of building energy is consumed by air conditioning system and rest 30\% is used for lighting and other utilities [17]. Thermal comfort depends on the heat gain or loss of interior side of building space. Temperature differences always prevail between interior and exterior side. That's why in cold region building space always loses its heat from interior to exterior and for this reason heating system is required into building space. But in hot climatic region there always exterior temperature is larger than interior. All buildings gain heat from outside space into interior space in hot climatic region and thus they require cooling system into building space [18]. The demand for heating or cooling for any space is called heating load and cooling load and it varies with region to region. So energy consumption due to thermal comfort is very significant. If the building envelope is properly designed and insulated it can save a significant amount of energy [19-21]. When the building envelope is properly insulated, it will reduce the heating and cooling demand. Well insulated wall has the ability to decrease the size of air conditioning system. The degree of insulation depends on the thermal properties of insulator used in building envelope. Heat transmission from interior to exterior is governed by thermal conductivity ( $k$ - value) of building envelope materials. Any insulation material with high $\mathrm{k}$ - value shows high insulative strength. If the materials have lower $\mathrm{k}$ - value then it has higher thermal resisting power. So selecting lower $\mathrm{k}$ value materials will be the best strategy to gain energy efficient building. The efficiency of building envelope is not only dependent on thermal properties of materials but also placement of it and proper placement of insulation helps to ensure the efficiency of building envelope [22]. In hot climatic zone reflective paint and coating on building envelope is very effective because it reflects most 
of the heat. Physical and thermal properties of different types of insulation materials are described below.

\subsection{Rock wool}

Rock wool is very good insulator both in hot and cold climatic region. Rock wool is also named as slag wool or mineral wool insulation. It is made from rock, blast furnace, sand and other raw materials. Natural rock is melted around $3000^{\circ}$ and the liquid rock is transferred into long fiber strands[19]. Finally these strands are used to create mats or bats for insulation. Rock wool is also a combination of sand that's why it works as a good insulator. A Sand or silicate type material does not store heat into them. They reflect the achieved heat as soon as possible. In hot climatic Zone reflection of any insulation is very important because $90 \%$ heat gain into building is created by solar radiation. Thermal Conductivity of rock wool is around (0.035 to 0.040$) \mathrm{W} / \mathrm{mK}[19,23,24]$.

\subsection{Glass wool}

Glass wool is a kind of insulating materials which is made of fiber of glass. Its texture is more like wool. Thick glass has uniform density and larger conductivity than fiber glass. Fiber glass has much void into them which makes it very good insulator. Air void into glass wool reduce its conductance and increase its thermal resistance. Gases (air) have less conductance than other materials like liquid and solid. In air heat transmit in convection process \& it needs more space to fulfill the convection process. In glass wool air is entrapped into that wool fiber void and tries to transfer heat in convection process. But the space between wool fibers is very small. That's why no convection process will occur and this entrapped air is used as an air thermal barrier. Glass wool comes from in mats and slabs form. Thermal conductivity of glass wool is around (0.023 -0.040) W/mK [25].

\subsection{Mineral wool}

Mineral wool is the combination of two insulator rock wool and glass wool (glass fiber). Two types of mineral wool are available in market light, soft and heavier, harder. Light and soft mineral wool products are used to fill up the cavities of building. Heavier and harder mineral wool boards are applied on load bearing elements of building like roofs and floors as well as work as thermal insulation. Thermal conductivity values of mineral wool are between 0.032 and $0.037 \mathrm{~W} / \mathrm{mK}[19,26]$.

\subsection{Glass fiber - foil -faced}

Glass fiber - foil -faced is a type of fiberglass blanket insulation. Glass fiber insulation is not more rigid and strong into adverse weather. A new form of glass fiber insulation discovered and is called foil faced glass fiber. It is made from thermosetting resin bonded with resilient glass fibers to form a lightweight, flexible glass wool blanket. Foil vapor barrier (FSK, Vinyl, Foil, WMP, and Kraft Facing) is provided into these blankets. The blanket also is used as additional insulation to fill voids in walls and roofs of metal buildings. Some company produces aluminum foil glass fiber. Its thermal property varies with the foil materials. Thermal property also depends on production procedure of the company. Average thermal conductivity of this type insulation is about $0.032 \mathrm{~W} / \mathrm{mK}$ [19, 26, 27].

\subsection{Expanded polystyrene}

A small spheres of polystyrene is used to produce expanded polystyrene (EPS). All small spheres are connected with each other so that it can make very dense bats or mats. Though EPS is produced as hard board insulation but it has a partly open pore structure. Thermal conductivity values for EPS are between 0.037 and $0.038 \mathrm{~W} / \mathrm{mK}[17,19,24,26]$.

\subsection{Extruded polystyrene}

Extruded polystyrene (XPS) is produced from melted polystyrene (from crude oil) by adding an expansion gas, e.g. HFC, $\mathrm{CO} 2$ or $\mathrm{C} 6 \mathrm{H} 12$, where the polystyrene mass is extruded through a nozzle with pressure release causing the mass to expand [19]. XPS has closed pore space. XPS surface is smoother than EPS because its pore spaces are 
closed. Normally thermal conductivity of XPS is between $(0.030-0.040) \quad \mathrm{W} / \mathrm{mK} \quad[20,26]$. Temperature and humidity has great impact on thermal conductivity. With increasing temperature and humidity thermal conductivity decreases.

\subsection{Polyurethane}

Polyurethane (PUR) is produced by a chemical reaction between isocyanates and polyols [19]. Normally it is used for manufacturing high resilience foam seating, surface coating and mostly for insulation of buildings. It is also used to fill up the cavities of windows and doors. Thermal conductivity of PUR is between (.025 - 0.03) $\mathrm{W} / \mathrm{m} . \mathrm{K}[19,26,28]$. Temperature and humidity has great impact on thermal conductivity. With increasing temperature and humidity thermal conductivity decreases. It can be cut into various size within requirement without changing its thermal properties.

\subsection{Natural rubber}

Primarily Natural rubber is made of some polymers and organic compound isoprene. Rubber is common insulating materials. It has two types natural and synthetic rubber. Most of the building uses synthetic rubber. It can be used as many forms and these materials include plastic, cork, wood, Styrofoam and rubber. Rubber thermal insulators are thus good at maintaining a consistent level of temperature whether hot or cold. The thermos acts as an insulator, keeping heat out. The properties of rubber will also cause the heat to slow down and eventually prevent them from moving from interior to exterior side. In cold region window and door cavities are filled with rubber so that no heat can be passed through the window. Windows are thermally insulated by providing rubber materials into their glass.

\subsection{Cork}

Cork is a form of bark tissue of phellem layer of Oak tree \& these barks are harvested commercially to produce cork. Basically Oak tree is greatly available in Europe and Africa. It has unique physical properties like bubble into the cork. This bubble helps the cork to increase thermal insulation \& resistance. For this reason, cork is suitable for application in building celling, facades walls. Cork can be produced as filler materials and plastic boards and typical thermal conductivity values for cork are between 0.032 and $0.043 \mathrm{~W} / \mathrm{mK}[19,24$, 29]. Cork insulation can be cut and perforated into various size within requirement without changing its thermal properties. For making thermally insulative concrete, granules of cork needs to be added into mixing of concrete within a reasonable ratio. Then it can produce very light weight thermally insulative concrete.

\subsection{Cellulose}

Cellulose (polysaccharide, $\left(\mathrm{C}_{6} \mathrm{H}_{10} \mathrm{O}_{5}\right) \mathrm{n}$ ) is one kind of thermal insulation produced by using reused paper or wood fiber mass[19]. Cellulose is a conventional thermal protection materials. It tends to be utilized as filler materials and for hard board moreover. Regularly thermal conductivity of cellulose is between $(0.022-0.033) \mathrm{W} / \mathrm{m} . \mathrm{K}$ [26, 29]. Cellulose can be cut into different size inside prerequisite without changing its warm properties.

\subsection{Air insulation}

Air consists of various types of gases like oxygen, nitrogen, hydrogen etc. Air can act as a very good thermal barrier. Heat can pass through air only by convection and radiation. It has very low thermal conductivity. So air film can be used as a good thermal insulation. Keeping some space between facade materials like open space between two wall layer can act as thermal barrier. But space between two wall layers should not be large, it should be optimum. If the wall layer space is greater than one inch, convection process will occur. Thermal conductivity of air is $0.026 \mathrm{~W} / \mathrm{mK}[19,23,28]$.

\subsection{Wood wool}

Wood wool is a product made from the sliver of wood which comes from tree logs. It has very physical strength \& rigidity. Their thermal conductivity is higher than other insulation material 
between 0.038 and $0.048 \mathrm{~W} / \mathrm{mK}[19,28,30]$. But in summer their thermal insulation increase. So for hot climatic region wood wool is very effective thermal insulation. It is used as rigid board on celling as a slab or as a wall but their specific thermal capacity and therefore summer heat insulation is higher than other materials, e.g. when installed in lofts' pitched roofs, wood wool boards offer better properties than basic dry wall systems in terms of summer heat insulation.

\subsection{Plywood}

Plywood is a kind of engineered wood which is made of wood sheet $\&$ the wood sheet materials are produced by adjoining thin layers of wood with glue. These sheet is also called wood veneer. Plywood is a common building materials. Plywood is generally used for door, window, wall, room separator etc. Thermal properties of plywood are quite same of hard wood. Both wood wool \& plywood is used as same purposes. But plywood has much more strength than normal wood wool. Plywood thermal conductivity depends on the panel boards. Its thermal conductivity is around 0.19 $\mathrm{W} / \mathrm{mK}$ [28].

\subsection{Plastic or high density polyethylene (HDPE)}

It is a combination of many synthetic or semi synthetic organic compounds. Sometimes plastic materials are used as building materials. Plastic is a polymer of various organic compounds. These plastic materials mixing with concrete can make good thermal insulation. Sometimes plastic materials are mixed with glass to make rigid glass. Thermal conductivity of polyethylene is between 0.41 to $0.51 \mathrm{~W} / \mathrm{mK}$ [28]. Plastic is not always used as facade, roof or ceiling. Sometimes it is used with some rigid materials for thermal insulation. Plastic has many forms and different plastic form has different thermal properties.

\subsection{Vermiculite}

Vermiculite is a hydrated magnesium-aluminumiron silicate. In lightweight plaster and concrete, vermiculite provides good thermal insulation.
Thermal conductivity of vermiculite is 0.065 $\mathrm{W} / \mathrm{mK}[19,28]$.

\subsection{Gypsum board}

Gypsum wallboard is used for room dividers, roofs, walls and that manages a surface appropriate to get decorated. Pre-decorated gypsum board is also used as surface dividers, roofs, or segments. Thermal conductivity of gypsum board is $0.17 \mathrm{~W} / \mathrm{mK}$ [19, 28].

\section{Renewable energy: Building Integrated Photovoltaic (BIPV)}

First of all, renewable energy is a type of energy that comes from the renewable sources using natural elements like solar radiation, wind, geothermal and bio-gas [31]. Renewable energy is a very efficient alternative way to use energy for daily life without harming the natural environment. Renewable energy sources have the potentiality to provide energy services with zero or almost zero emissions of both air pollutants and greenhouse gases and recently renewable energy sources supply $14 \%$ of the total world energy demand [32]. There are four common sources of renewable energy like Photovoltaic system, Wind turbine system, Geothermal system and Bio-gas systems. But in residential site, all options are not equally applicable. A residential building does not produce enough waste that can run a bio-gas plant. The best renewable energy options for residential building are photovoltaic and wind turbine system. Recently building integrated photovoltaic (BIPV) system has paved a new way to cultivate energy from solar radiation. BIPV is a kind of photovoltaic panels which are used in replace of conventional building parts like roof, facade and window. "Building Integrated Photovoltaic (BIPV) is a PV application close to being capable of delivering electricity at less than the cost of grid electricity to end users in certain peak demand"[33]. Application of BIPV depends on some factors such as climate, builtenvironment, building structure, orientation and government policies. In this study, only the building parts roof and window were analyzed for calculating how much PV energy it can produce. It 
is very necessary to know the potentiality of BIPV for generating PV energy after installing them on building parts like window and roof at design phase for developing NZEB. PV panel can be mounted on roof. But only roof mounting PV (in Fig. 2) is not able to produce enough energy to fulfill total energy demand of the building. Recently many companies produce transparent PV panels (in Fig. 3) and these transparent PV panels can be used as building window, balcony materials and stair headroom as well as extra PV panel on building footprint. In this study, PV panels are installed on roof, windows, balcony and stair headroom exterior surface of prototype residential building.

\section{Methodology}

Design phase is the most important period to take decision for developing NZEB. It is very essential to select appropriate energy efficient options for building envelope, orientation, window wall ratio, Window types, HVAC systems etc. at design phase.

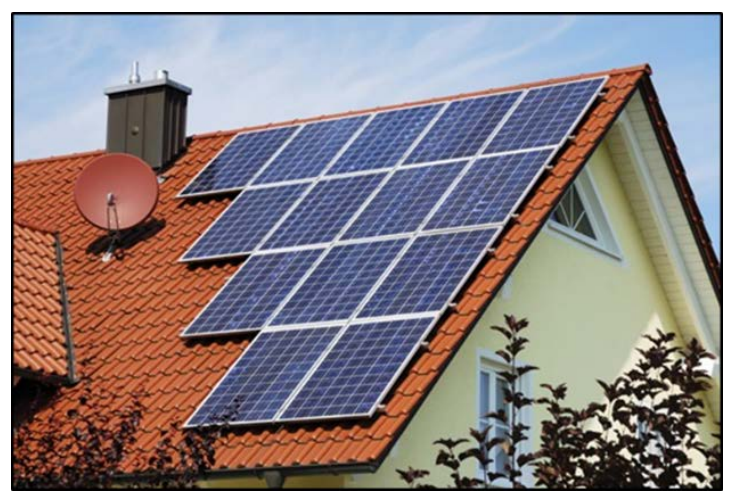

Fig. 2. Roof mounted PV panel

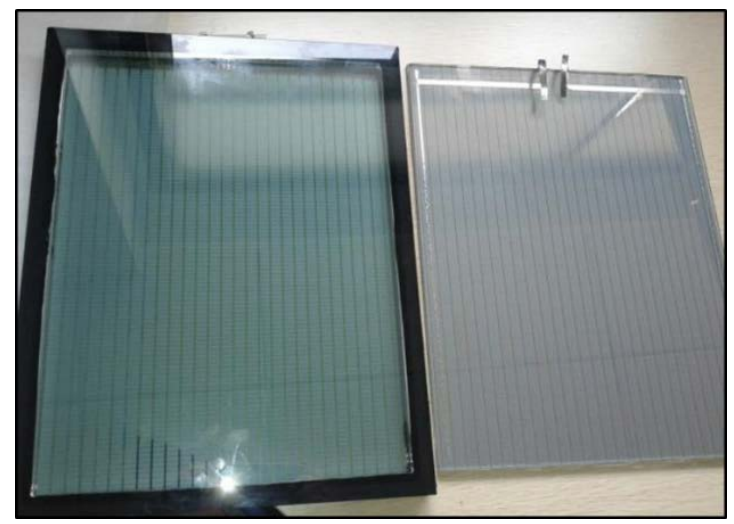

Fig. 3. Transparent PV panel
But in this study building envelope, orientation and air conditioning systems were considered for analysis. Building Information Modeling (BIM) has the emerging impact on construction industry for various purposes [34]. Research regarding energy efficient building greatly depends on BIM due to its productivity and accuracy. In the past, building energy simulations were done by spread sheet, Microsoft-excel or by hand. These simulations were very time consuming and results were not accurate because it could not consider all energy factors at a time. In this study, it focuses on BIM technology based building energy simulations. Three BIM tools (Autodesk Revit 2017, Autodesk Green Building Studio and BIM Insight 360) were used for completing this study. Main goal is to find out the best envelope materials and orientation at design phase using BIM. For this reason, Autodesk Revit is very useful due to its parametric characteristics. A prototype residential building was created in Revit because it can help to change the envelope materials and orientation frequently due to its parametric characteristics. About 61 scenarios were created using different types of envelope materials and orientation. Whole building energy simulation was done using Autodesk Green Building Studio (GBS) after transporting each combinations as gbXML file. Whole study was executed according to Fig. 4.

This study started with rigorous literature review about building sciences and physics. Building science helps to optimize building performances. Various types of building envelope materials, thermal properties of insulator and building orientations were studied. The impacts on energy consumption of these factors were also studied. In second step, a multi-storey residential building was built as a prototype energy model. Energy performance will be evaluated at design phase towards net zero energy building. The 3D model of the building was created by Autodesk Revit 2017. The demo energy model was a single unit eight storey B shaped residential building. It has two bedroom, one living room and one dining room. Total floor and exterior wall area of eight storey was 10588 sft \& 10197 sft respectively. 


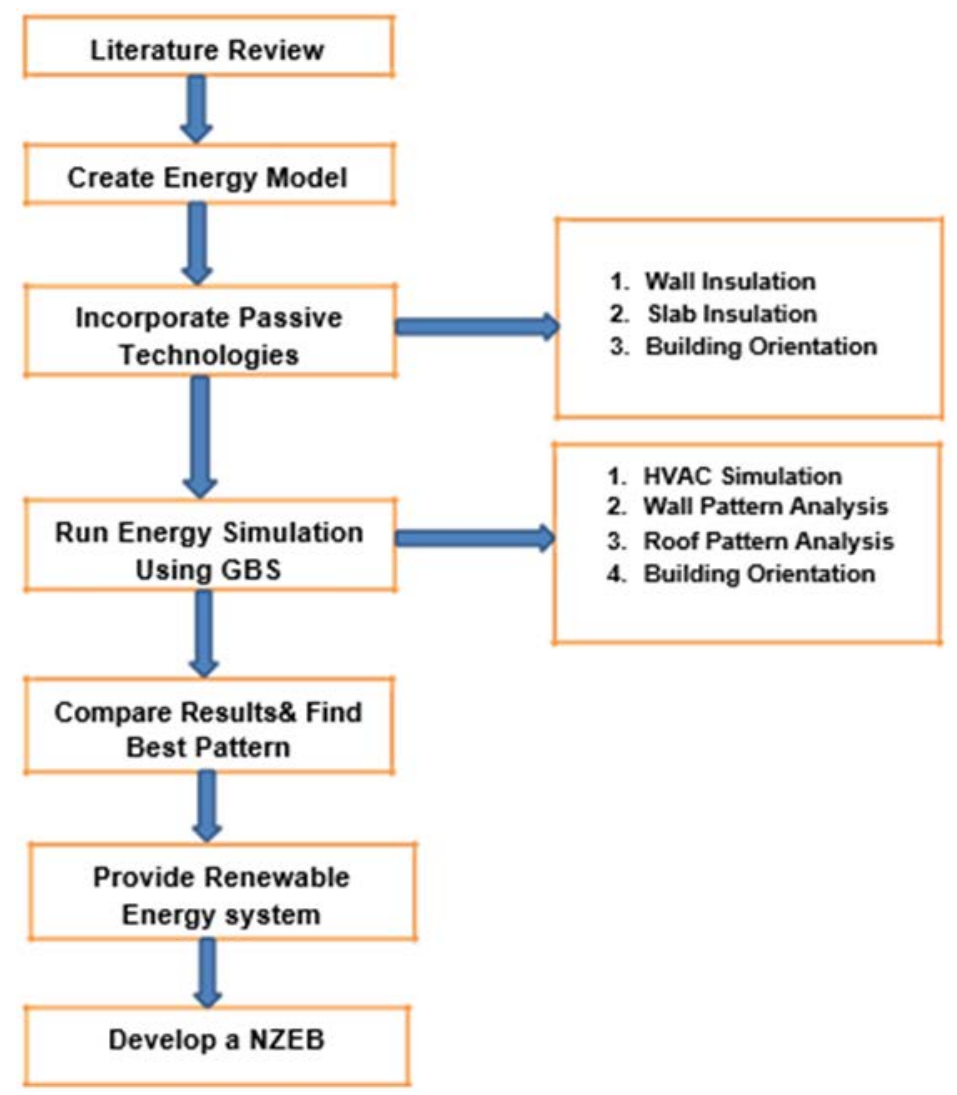

Fig. 4. Flowchart of this study

Building conceptual mass model energy simulation and detailed element energy simulation process are installed in Autodesk Revit. Detailed element method was used in this study for energy simulation. It has advanced energy setting which can help to incorporate different types of energy optimization options and passive house technologies. Energy parameter needs to be set for creating energy model of that demo residential model. Important energy parameters include building location for weather data, building type, building operating schedule and HVAC system. Location of the project is Khulna, Dhaka, Bangladesh and coordinate is $\mathrm{N} 22.8456, \mathrm{E}$ 89.5403. An analytical energy model was created after setting energy parameters for making a gbXml file which is readable to green building studio (GBS). Fig. 5 and Fig. 6 represent building plan and thermal zoning area of the residential buildings. The third and most important step was to incorporation of passive technologies such as building energy efficient envelope and orientation into the prototype energy model. The prototype residential building energy model location is Khulna, Dhaka, Bangladesh. It is in warm - humid region. Solar heat gain is very predominant in this region. Building interior space can gain a lots of solar heat from outside and for this reason it requires large air conditioning system. So by reducing the heat gain simultaneously, it can reduce the cooling load and air conditioning system size. When air condition size is reduced, energy consumption will also be reduced. Wall insulation is essential for reducing heat gain. If the wall is properly insulated and designed it can reduce significant amount of energy consumption by lowering the cooling load. There are several types of insulation and building envelope materials and their thermal properties are different from each other. 


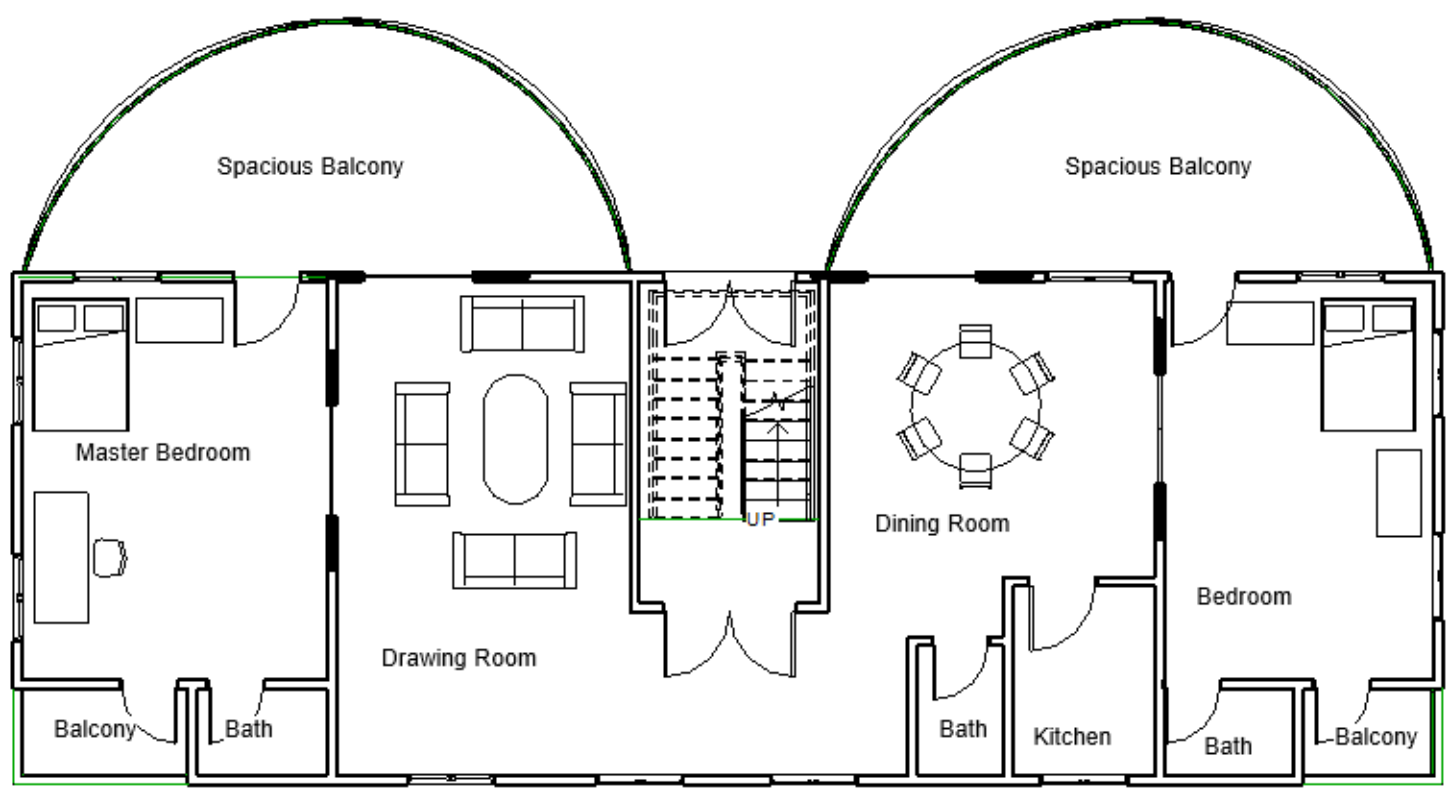

Fig. 5. Plan view of demo residential building

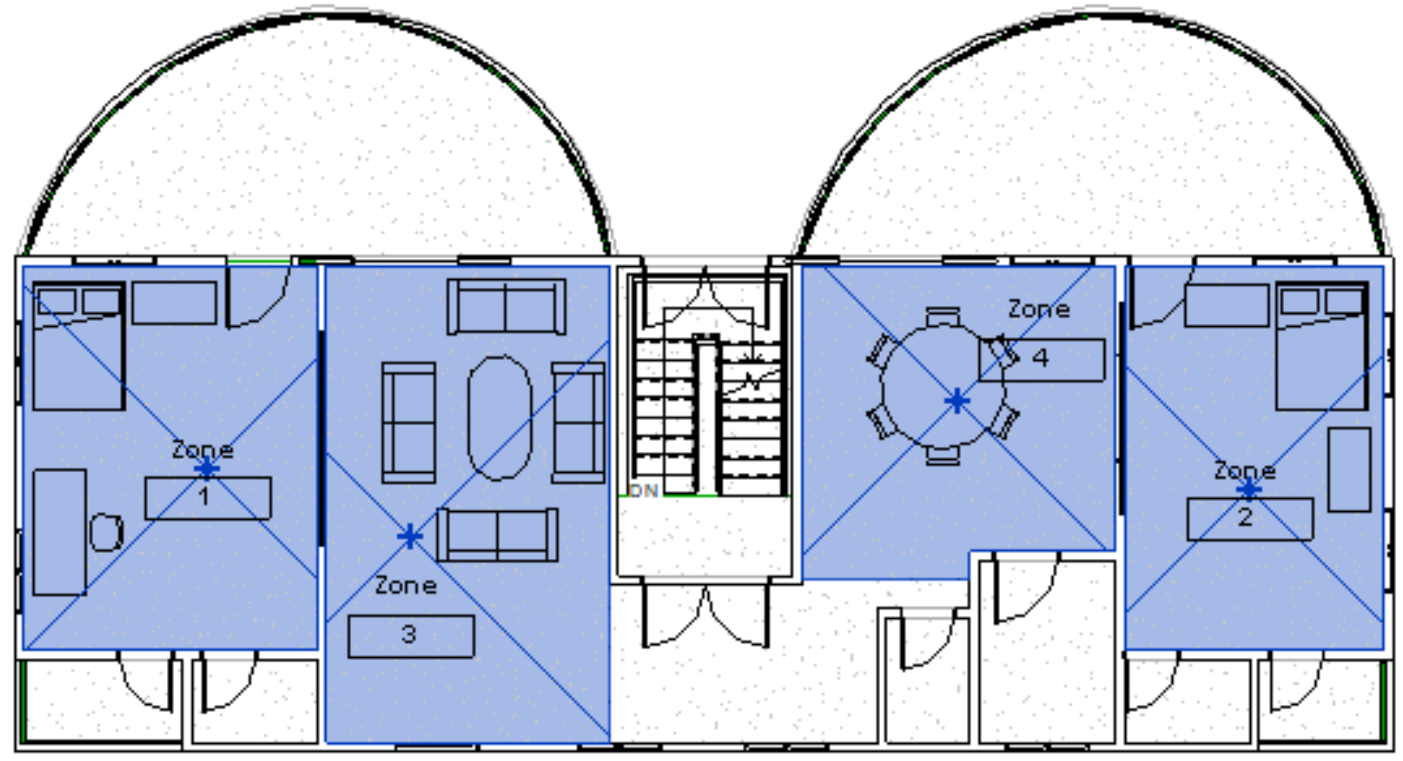

Fig. 6. Typical floor of thermal zoning

This research made 31 combination of walls by using different types of insulation and building envelope materials. Materials were installed into walls by making a different layer. Fig. 7 represents the skeleton of building wall and placement of envelope materials and insulation on building wall.
Wall thickness kept constant at 5 inch. It was assumed that building wall served as non-structural element. Wall combinations were used as thermal barrier only between indoor and outdoor space. Table 1 represents the 31 wall combinations and envelope materials. 
Table 1. Different types of wall combinations

\begin{tabular}{|c|c|}
\hline $\begin{array}{l}\text { Wall combinations } \\
\text { Name }\end{array}$ & Combinations of Building Envelope and Insulation Materials \\
\hline Wall 1 & 2.5 inch brick wall +1 inch rubber +1.5 inch wood wool \\
\hline Wall 2 & 2.5 inch brick wall +1.5 inch polystyrene +1 inch hard wood \\
\hline Wall 3 & 2.5 inch brick wall +1.5 inch fiberglass +1 inch plastic board \\
\hline Wall 4 & 2.5 inch brick wall +1 inch cellulose +1.5 inch rock wool \\
\hline Wall 5 & 2.5 inch brick wall + 1 inch cork + 1.5 inch plywood wood \\
\hline Wall 6 & 2.5 inch brick wall + 1 inch cavity air + 1.5 inch plastic board \\
\hline Wall 7 & 2 inch brick wall +1 inch rubber +2 inch light weight concrete \\
\hline Wall 8 & 2 inch brick wall +1 inch straw fiber +2 inch brick wall \\
\hline Wall 9 & 3 inch brick wall +1 polyurethane +1 inch hard wood \\
\hline Wall 10 & 0.5 inch aluminum coating +2.5 inch brick wall +2 inch glass fiber \\
\hline Wall 11 & 2.5 inch light weight concrete +1 inch rubber +1.5 inch wood wool \\
\hline Wall 12 & 2.5 inch light weight concrete +1.5 inch polystyrene +1 inch hard wood \\
\hline Wall 13 & 2.5 inch light weight concrete +1.5 inch fiberglass +1 inch plastic board \\
\hline Wall 14 & 2.5 inch light weight concrete +1 inch cellulose +1.5 inch rock wool \\
\hline Wall 15 & 2.5 inch light weight concrete +1 inch cork +1.5 inch plywood wood \\
\hline Wall 16 & 2.5 inch light weight concrete +1 inch cavity air +1.5 inch plastic board \\
\hline Wall 17 & 2 inch light weight concrete +1 inch rubber +2 inch light weight concrete \\
\hline Wall 18 & 2 inch light weight concrete +1 inch straw fiber +2 inch brick wall \\
\hline Wall 19 & 3 inch light weight concrete +1 polyurethane +1 inch hard wood \\
\hline Wall 20 & 0.5 inch aluminum coating +2.5 inch light weight concrete +2 inch glass fiber \\
\hline Wall 21 & 2 inch brick wall +1 inch vermiculite +2 inch brick wall \\
\hline Wall 22 & 5 inch brick wall \\
\hline Wall 23 & 5 inch concrete \\
\hline Wall 24 & 1 inch metal +1 rock wool +2 inch Wood \\
\hline Wall 25 & 3 inch light weight concrete +1 inch foil faced glass +1.5 inch gypsum board \\
\hline Wall 26 & 2 inch brick wall +1 inch vermiculite +2 inch light weight concrete \\
\hline Wall 27 & 2 inch brick wall + 1 inch rock wool +2 inch light weight concrete \\
\hline Wall 28 & 2 inch brick wall +1 inch polyurethane +2 inch light weight concrete \\
\hline Wall 29 & 2 inch brick wall +1 inch wood wool +2 inch light weight concrete \\
\hline Wall 30 & 2.5 inch brick wall +1 inch Rubber +2 inch light weight concrete \\
\hline Wall 31 & 5 inch light weight concrete \\
\hline
\end{tabular}

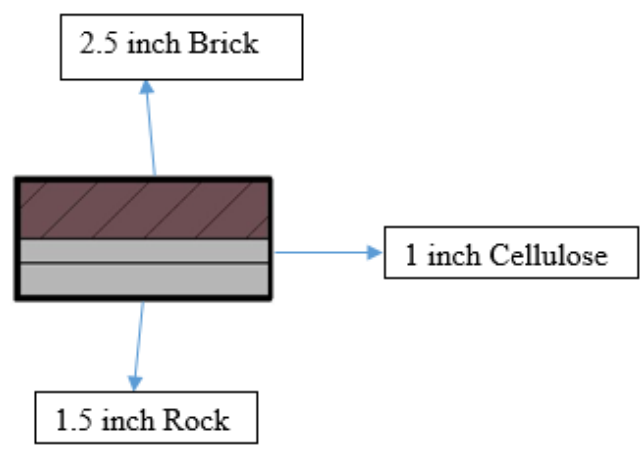

Fig. 7. Example of the Skeleton wall pattern
Since it is a multi-stroey building, heat gain through roof is less than through building exterior wall. Heat gain causes at the eight floor only through roof. About 10 roof combinations were made using concrete and other insulation. Insulation materials have been provided at the bottom of the roof. Fig. 8 represents the skeleton of building roof and placement of envelope materials and insulation on building roof. Table 2 represents the 10 roof combinations and envelope materials. 
Table 2. Different types of roof combinations

\begin{tabular}{ll}
\hline $\begin{array}{l}\text { Wall combinations } \\
\text { Name }\end{array}$ & Combinations of Building Envelope and Insulation Materials \\
\hline Roof 1 & 6 inch concrete +2 inch expanded polystyrene \\
Roof 2 & 6 inch concrete +2 inch Rubber \\
Roof 3 & 6 inch concrete +2 inch mineral wool \\
Roof 4 & 6 inch concrete +2 inch cork \\
Roof 5 & 6 inch concrete +2 cellulose \\
Roof 6 & 6 inch concrete +2 inch gypsum board \\
Roof 7 & 6 inch concrete +2 inch rock wool \\
Roof 8 & 6 inch concrete +2 inch polyurethane \\
Roof 9 & 6 inch concrete +2 inch wood \\
Roof 10 & 6 inch concrete +2 inch foil faced glass fiber \\
\hline
\end{tabular}

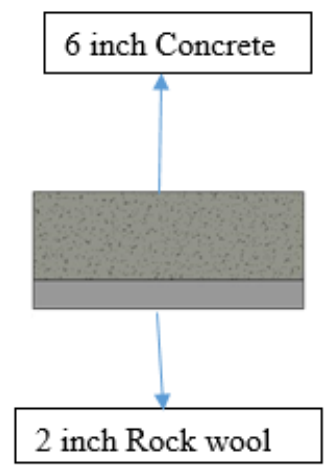

Fig. 8. Example of the Skeleton roof pattern

Another important passive element of building is proper orientation. If a building is properly orientated, it can obstruct huge amount of direct solar heat gain from sun. The sun rays acts on building within different angle. The intensity of sun light depends on the sun angle and orientation of building also. Proper correlation of sun angle and building orientations can reduce significant amount of heat gain. Building initial position was displayed in Fig. 9 before rotating. In this study building was rotated within $45^{\circ}$ angle interval anticlockwise from project north side. Total eight combinations were made for building rotation. Table 3 represents the combination of orientations. After incorporating all passive technologies, the fourth step was to simulate energy for different combinations. Fig. 10 shows total simulation process for various combinations. Firstly a prototype residential building was created using Autodesk Revit. All passive combinations regarding building envelope and orientation were incorporated into the prototype building. Then energy settings were made according to building purpose. After that analytical energy model was developed and transferred as gbXML file to Green Building Studio (GBS) for energy simulations. Simulations were done for each combination of building envelope and orientation. Objective of this simulations was to find out the contribution of various combinations on energy consumption. While simulating a single combination, all other building factors were kept constant. So that it can measure the effect of a single combination on energy consumption. For example when a combination named wall 1 (2.5 inch brick wall +1 inch rubber +1.5 inch wood wool) incorporated into prototype building as building envelope, all other building factors like HVAC systems, window wall ratio and orientations were kept constant. Keeping the same building condition, total 31 wall combinations were simulated according to the process of Fig. 10. Building energy consumption depends on various active systems like HVAC systems, lighting, oven and mechanical ventilation etc. HVAC system has larger impact on energy consumption than all other active systems. 


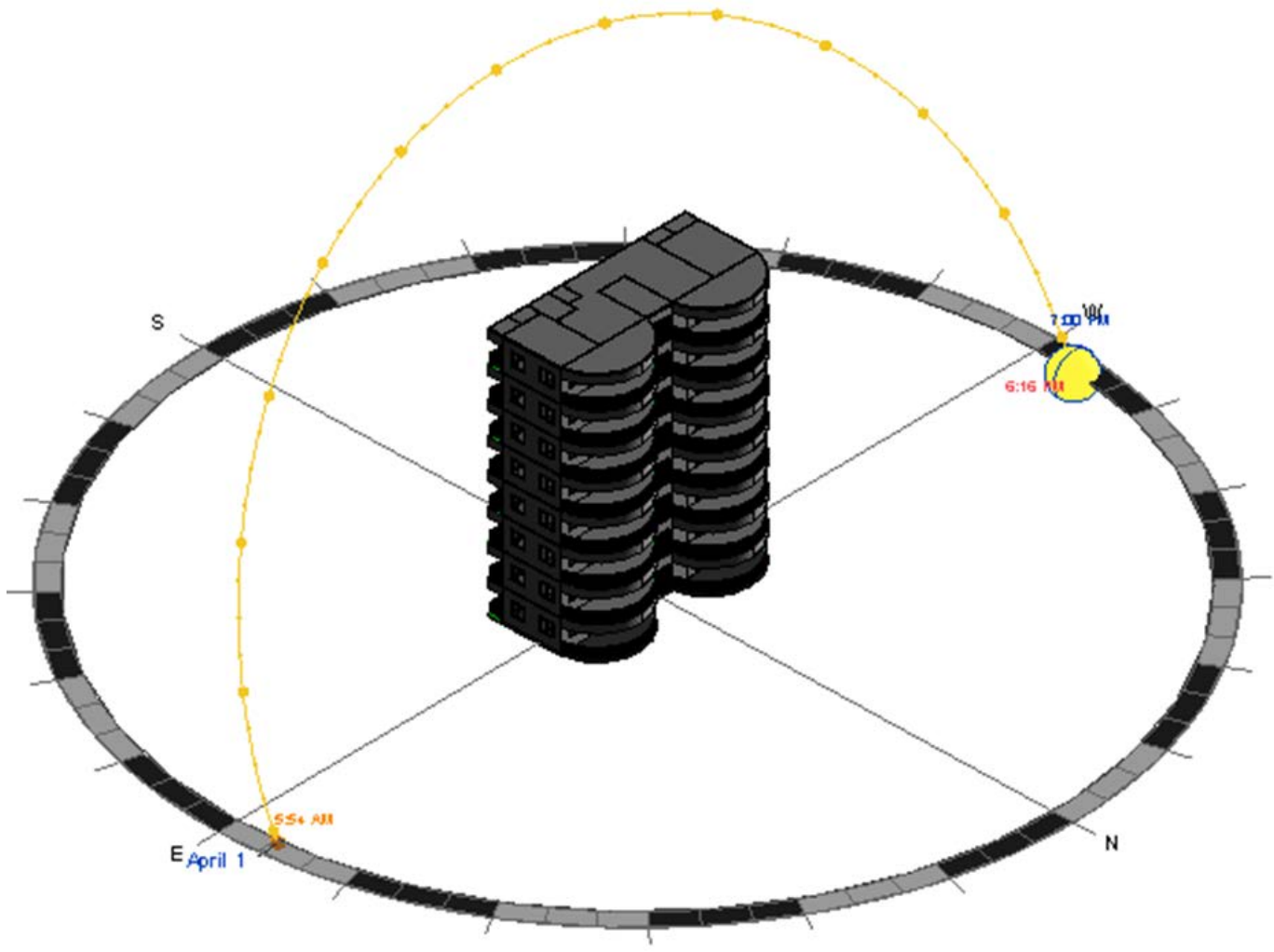

Fig. 9. Initial position of the prototype building

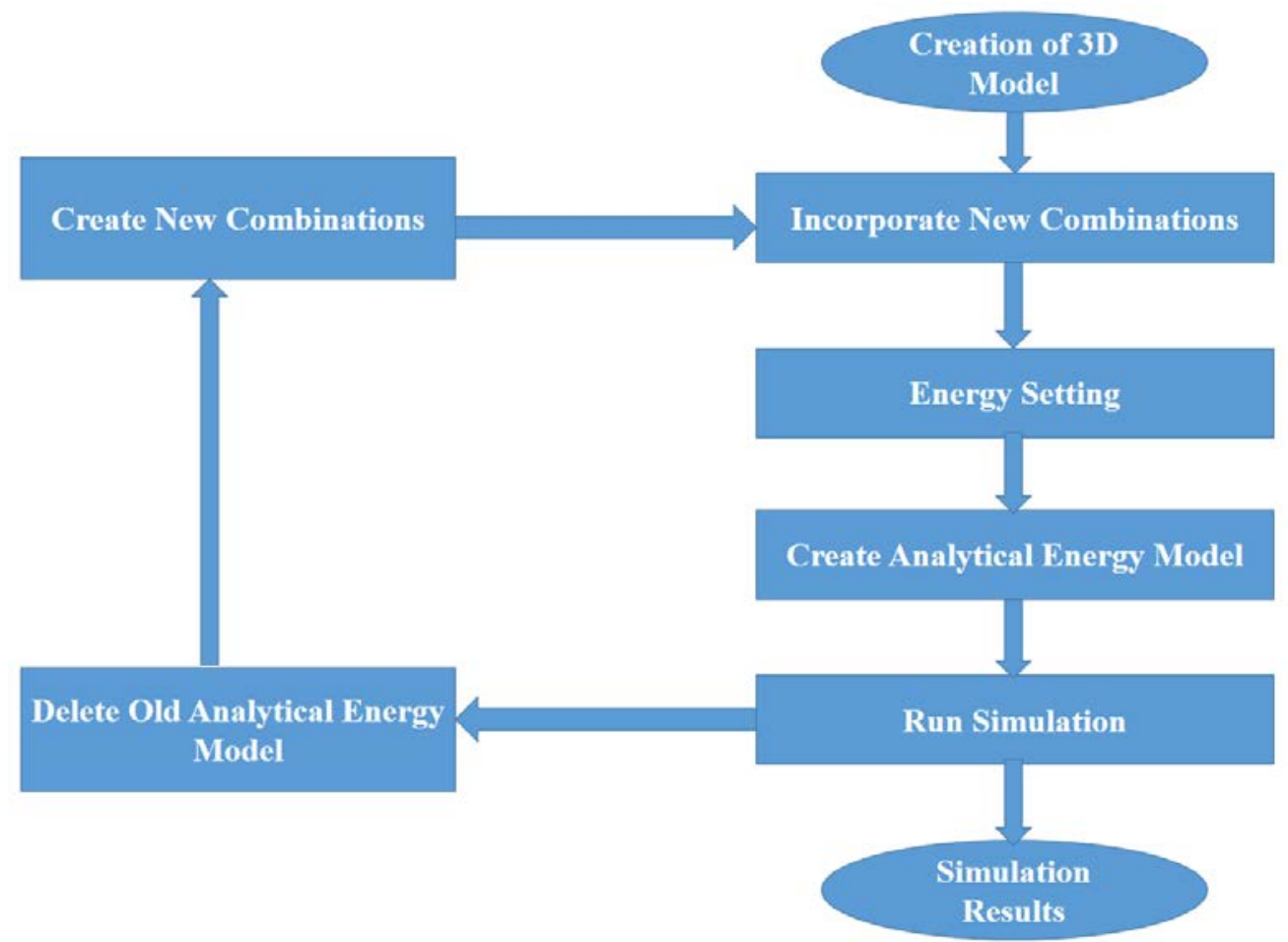

Fig. 10. Energy simulation process diagram 
Table 3. Different types of orientation combinations

\begin{tabular}{cc}
\hline Name of the combinations & Building rotation angle \\
\hline Rotation 1 & $0^{0}$ \\
Rotation 2 & $45^{0}$ \\
Rotation 3 & $90^{0}$ \\
Rotation 4 & $135^{0}$ \\
Rotation 5 & $180^{0}$ \\
Rotation 6 & $225^{0}$ \\
Rotation 7 & $270^{0}$ \\
Rotation 8 & $315^{0}$ \\
\hline
\end{tabular}

It was necessary to select the efficient HVAC system after incorporating passive technologies. In this study only the Revit built-in HVAC systems were being used for analysis. Table 4 represents HVAC systems name and their run name. In this study HVAC systems, building envelope and orientation considered for simulation. Building envelope was divided as wall pattern and roof pattern for simulation. In Table 5 run names for energy simulation are given for wall pattern analysis, roof pattern analysis, building orientation and HVAC simulation.

Energy parameters need to be fixed before energy simulation of any building. Parameters are set according to building purpose and occupants of it. Two energy simulation processes are available in Revit 2017 such as building conceptual mass model energy simulation and detailed element energy simulation. The energy setting varies with simulation method. Conceptual method has one type of energy setting and detailed element method has another energy setting. In conceptual method, energy is calculated with respect to its space and room only. It will not consider any passive technology or material properties. Detailed element method is a type of energy simulation process on which it will consider all types of passive technologies and building materials. It has a unique type of energy setting. In this research detailed element method was implemented for energy simulation. Detailed element method has advanced energy setting option which can help to incorporate different types of energy optimization options. In Fig. 11(a) and 11(b) represents the energy settings and different important energy options are described below.

\begin{tabular}{|c|c|c|c|}
\hline I] & rgy Settings & & $x$ \\
\hline Parameter & Value & & $\hat{\wedge}$ \\
\hline Essential & & $\hat{\imath}$ & \\
\hline Location & $22.8456,89.5403$ & & \\
\hline Energy Analytical Model & & $\hat{\imath}$ & \\
\hline Mode & Use Building Elements & & \\
\hline Ground Plane & Level 1 & & \\
\hline Project Phase & New Construction & & \\
\hline Analytical Space Resolution & $1^{\prime} 6^{\prime \prime}$ & & \\
\hline Analytical Surface Resolution & $10^{\prime \prime}$ & & \\
\hline Perimeter Zone Depth & $12^{\prime} 0^{\prime \prime}$ & & \\
\hline Perimeter Zone Division & $\checkmark$ & & \\
\hline Advanced & & $\hat{\imath}$ & $\checkmark$ \\
\hline
\end{tabular}

a. Energy setting toolbar in Revit

\begin{tabular}{|l|l|}
\hline \multicolumn{3}{|c|}{ Advanced Energy Settings } \\
\hline \multicolumn{1}{|c|}{ Parameter } & \multicolumn{2}{|c|}{ Value } \\
\hline Building Data & \\
\hline Building Type & Multi Family \\
\hline Building Operating Schedule & $24 / 7$ Facility \\
\hline HVAC System & Residential 14 SEER/0.9 AFUE Split/Pac \\
\hline Outdoor Air Information & \\
\hline Room/Space Data & \\
\hline Export Category & Spaces \\
\hline Material Thermal Properties & \\
\hline Conceptual Types & \\
\hline Schematic Types & $\langle$ Building \\
\hline Detailed Elements & $\mathbf{\checkmark}$ \\
\hline
\end{tabular}

b. Advanced energy setting toolbar in Revit

Fig. 11. Energy settings and important energy options 
Table 4. HVAC combinations

\begin{tabular}{cc}
\hline Run Name & Name of HVAC systems \\
\hline HVAC 1 & 12 SEER/0.9 AFUE Split/Packaged Gas, 5-11 Ton \\
HVAC 2 & 11.3 EER Packaged VAV, 84.4\% boiler heating \\
HVAC 3 & Central VAV, HW Heat, Chiller 5.96 COP, Boilers 84.5 eff \\
HVAC 4 & 4-Pipe Fan Coil System, Chiller 5.96 COP, Boilers 84.5 eff \\
HVAC 5 & Central VAV, Electric Resistance Heat, Chiller 5.96 COP \\
HVAC 6 & 12 SEER/7.7 HSPF Split Packaged Heat Pump \\
HVAC 7 & 2-Pipe Fan Coil System, Chiller 5.96 COP, Boilers 84.5 eff \\
HVAC 8 & 12 SEER/8.3 HSPF Packaged Terminal Heat Pump (PTAC) \\
HVAC 9 & Residential 17 SEER/ 9.6 HSPF split HP<5.5 ton \\
HVAC 10 & Underfloor Air Distribution \\
HVAC 11 & Residential 14 SEER/ .9 AFUE packaged gas $<5.5$ ton \\
HVAC 12 & Residential 17 SEER/ 9.6 HSPF split packaged heat pump \\
\hline
\end{tabular}

Table 5. Run name for different combinations

\begin{tabular}{|c|c|c|c|}
\hline $\begin{array}{l}\text { HVAC Simulation } \\
\text { Run Names }\end{array}$ & $\begin{array}{l}\text { Wall Thermal Analysis } \\
\text { Run Names }\end{array}$ & $\begin{array}{c}\text { Roof Analysis Run } \\
\text { Names }\end{array}$ & $\begin{array}{l}\text { Building Orientation } \\
\text { Run Names }\end{array}$ \\
\hline HVAC 1 & Wall 1, Wall 2, Wall 3, & Roof 1 & Rotation $1-0^{0}$ \\
\hline HVAC 2 & Wall 4, Wall 5, Wall 6, & Roof 2 & Rotation $2-45^{0}$ \\
\hline HVAC 3 & Wall 7, Wall 8, Wall 9, & Roof 3 & Rotation $3-90^{0}$ \\
\hline HVAC 4 & Wall 10, Wall 11, Wall 12, & Roof 4 & Rotation $4-135^{0}$ \\
\hline HVAC 5 & Wall 13, Wall 14, Wall 15, & Roof 5 & Rotation $5-180^{\circ}$ \\
\hline HVAC 6 & Wall 16, Wall 17, Wall 18, & Roof 6 & Rotation $6-225^{0}$ \\
\hline HVAC 7 & Wall 19, Wall 20, Wall 21, & Roof 7 & Rotation $7-270^{\circ}$ \\
\hline HVAC 8 & Wall 22, Wall 23, Wall 24, & Roof 8 & Rotation $8-315^{0}$ \\
\hline HVAC 9 & Wall 25, Wall 26, Wall 27, & Roof 9 & \\
\hline HVAC 10 & Wall 28, Wall 29, Wall 30, & Roof 10 & \\
\hline HVAC 11 & Wall 31. & & \\
\hline HVAC 12 & & & \\
\hline
\end{tabular}

- Location: Weather data is essential for energy analysis. Green Building Studio executes energy simulation considering the weather data of building location. Revit has interoperability with Green Building Studio (GBS). GBS is a cloud based computational software. Location of the prototype project was Khulna, Dhaka, Bangladesh and coordinate was N 22.8456, E 89.5403.
- Mode: This option describes about simulation methods which will be applied to analyze like conceptual method or detail method or conceptual and detailed method both. Building detailed element method was chosen for simulation.

- Building type: It represents the purpose of building. Having multiple options like office, commercial building, residential multifamily, 
warehouse, office, museum, library, motel etc. So from them multifamily option was selected because the project was residential building project.

- Building operating schedule: Since the project is residential. So there are always need 24 hours and seven days facilities within the week.

The last step was to simulate the prototype building for calculating renewable energy production potentiality. A building has much potentiality for producing renewable energy by using its footprint and elements. It is necessary to calculate the potentiality of a building for producing renewable energy at design phase. BIM technology has made a simple way to evaluate renewable potentiality of any building. Potentiality of renewable energy can also be calculated by theoretical means. In this study both BIM technology and theoretical process were applied to calculate renewable energy potential of prototype residential building. Building Integrated Photovoltaic system implemented on roof, window, railing of balcony and head room of stair. In Fig. 12, blue color marking areas represent the installation of BIPV on them. Autodesk Insight 360 was used to estimate the potentiality of renewable energy.

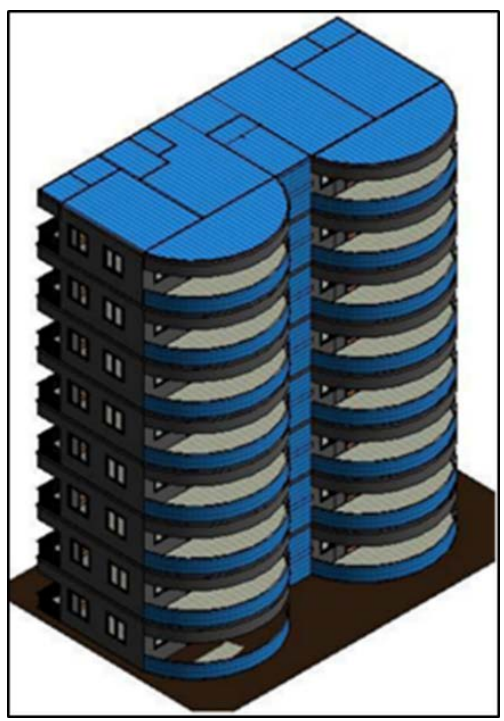

Fig. 12. Installation of Building Integrated PV panels (BIPV)

\section{Results and discussion}

Simulation results of different combinations are compared within three main criteria such as (1) life cycle cost, (2) annual electricity cost and (3) annual carbon emissions. Life cycle cost refers to the amount of cost that will be occurred for running all building facilities throughout whole life of any building. Green Building Studio assumed 30 years for life cycle period. Annual carbon emission represents the amount of emission of carbon dioxide due to energy consumption annually because energy comes from burning of fossil fuel. According to US department of energy, around 1.22 lbs. $\mathrm{CO}_{2}$ will emit by using per $\mathrm{kWh}$ and 0.000548 metric tons of $\mathrm{CO}_{2}$ by using per therm natural gas. Carbon emission will vary from region to region. In India carbon emission is 0.91 to $0.95 \mathrm{~kg}$ for per $\mathrm{kWh}$ [35]. 31 wall, 10 roof, 12 HVAC and 10 rotation combinations were created respectively in this study. Simulation results of different combinations were compared with each other. Any combination represents lower life cycle cost, annual energy cost and carbon emission than other combination will be the best passive pattern. Fig. 13 represents the life cycle cost for different combination. Horizontal axis expresses the amount of cost and vertical axis represents subscript of any combination. For example vertical axis value 1 represents HVAC 1, Wall 1, Roof 1 and Rotation 1 combination. In Figure 14 and Figure 15 horizontal axis represents annual energy cost and carbon emission respectively and vertical axis represent subscript of different combinations.

Comparison of wall pattern analysis: After analyzing 31 Wall combination simulation results, wall 13 caused minimum life cycle cost (\$127445), annual energy cost (\$9357) and carbon emission (35.9 tons). Figs. 13-15 also show minimum life cycle cost, annual energy cost and carbon emission for Wall 13. Maximum value is represented by Wall 23 combination. Wall 13 combination consists of 2.5 inch light weight concrete +1.5 inch fiberglass +1 inch plastic board. 


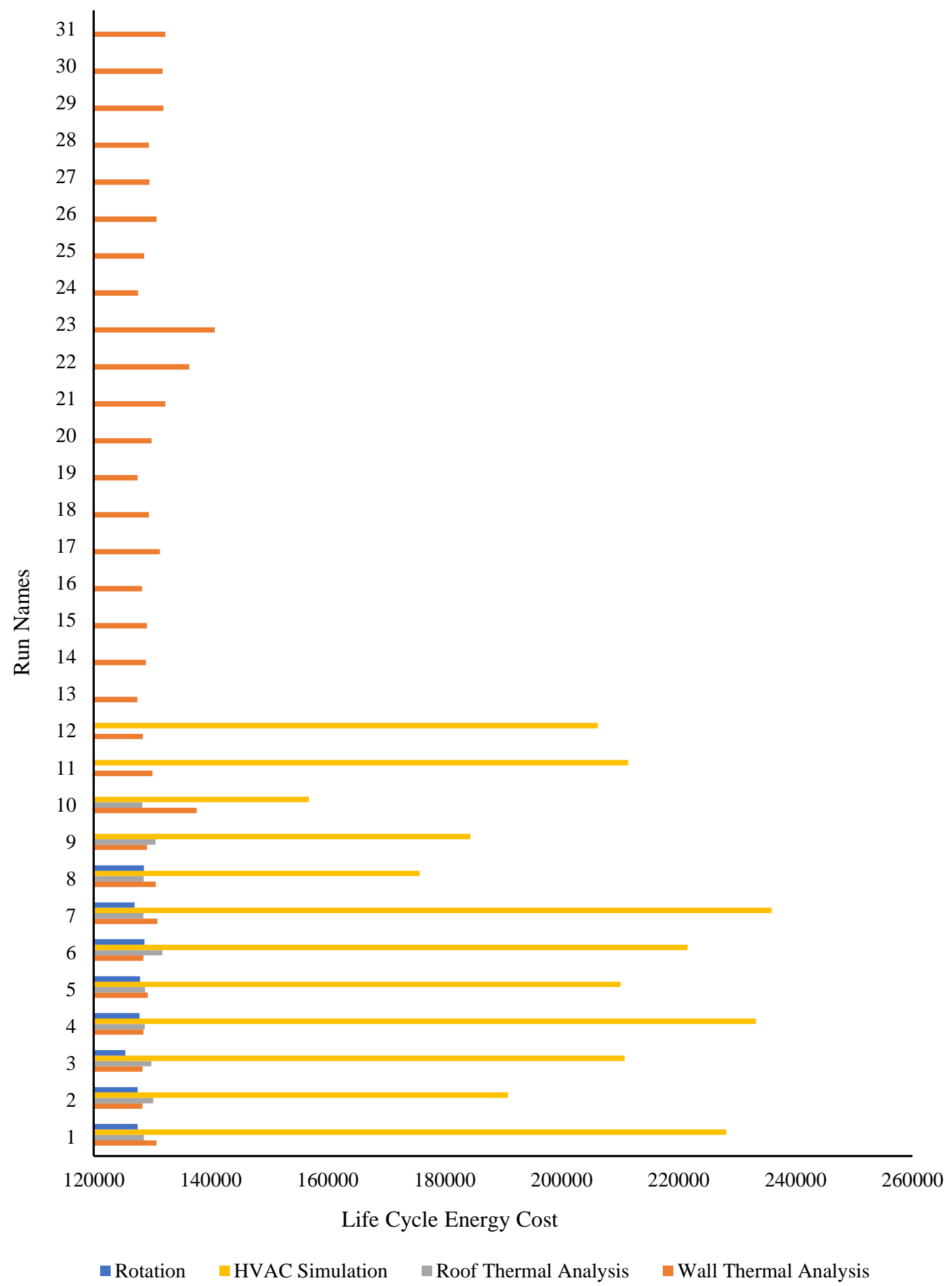

Fig. 13. Life cycle cost for different combinations 


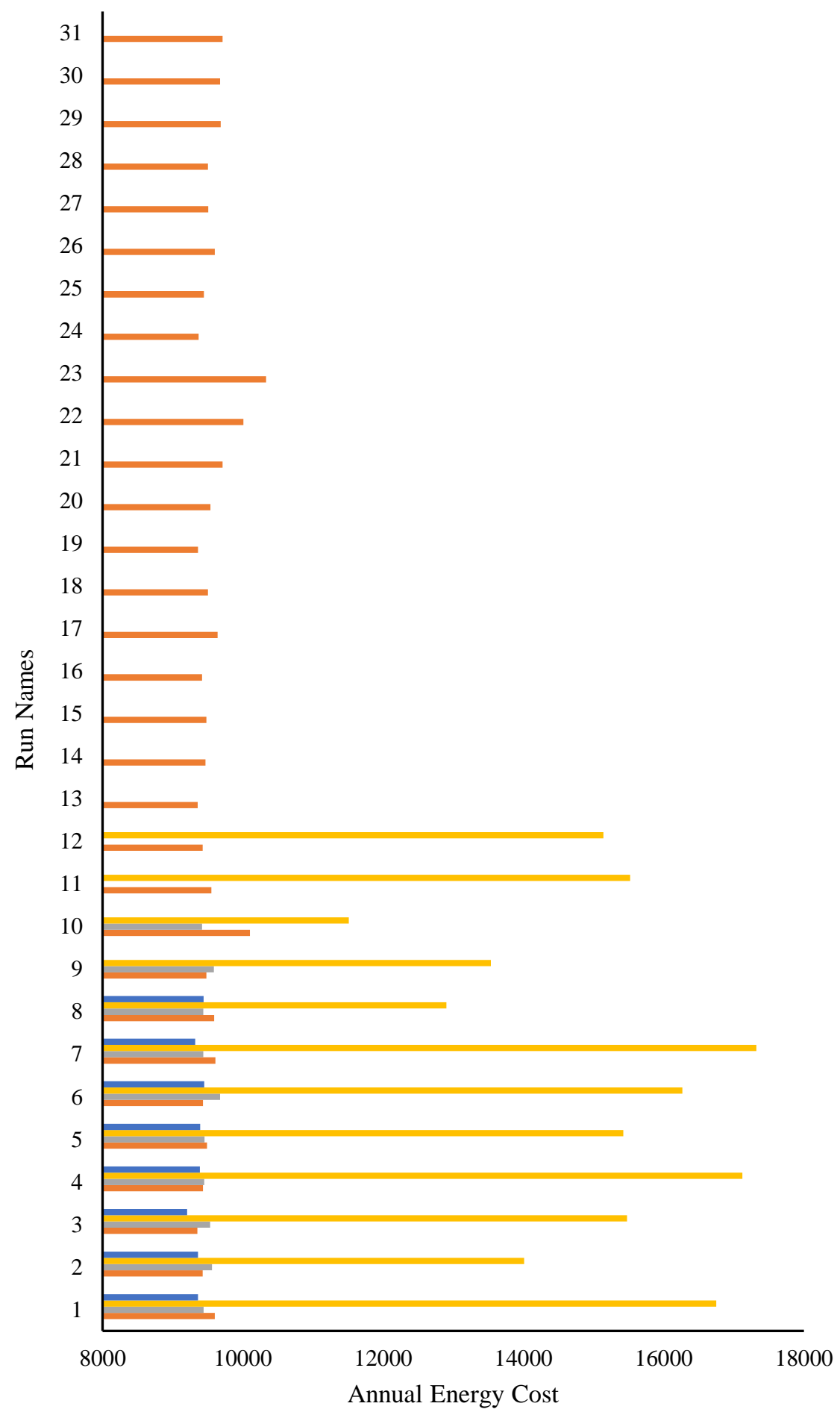

- Rotation $\quad$ HVAC Simulation $\quad$ Roof Thermal Analysis $\square$ Wall Thermal Analysis

Fig. 14. Annual energy cost for different combinations 


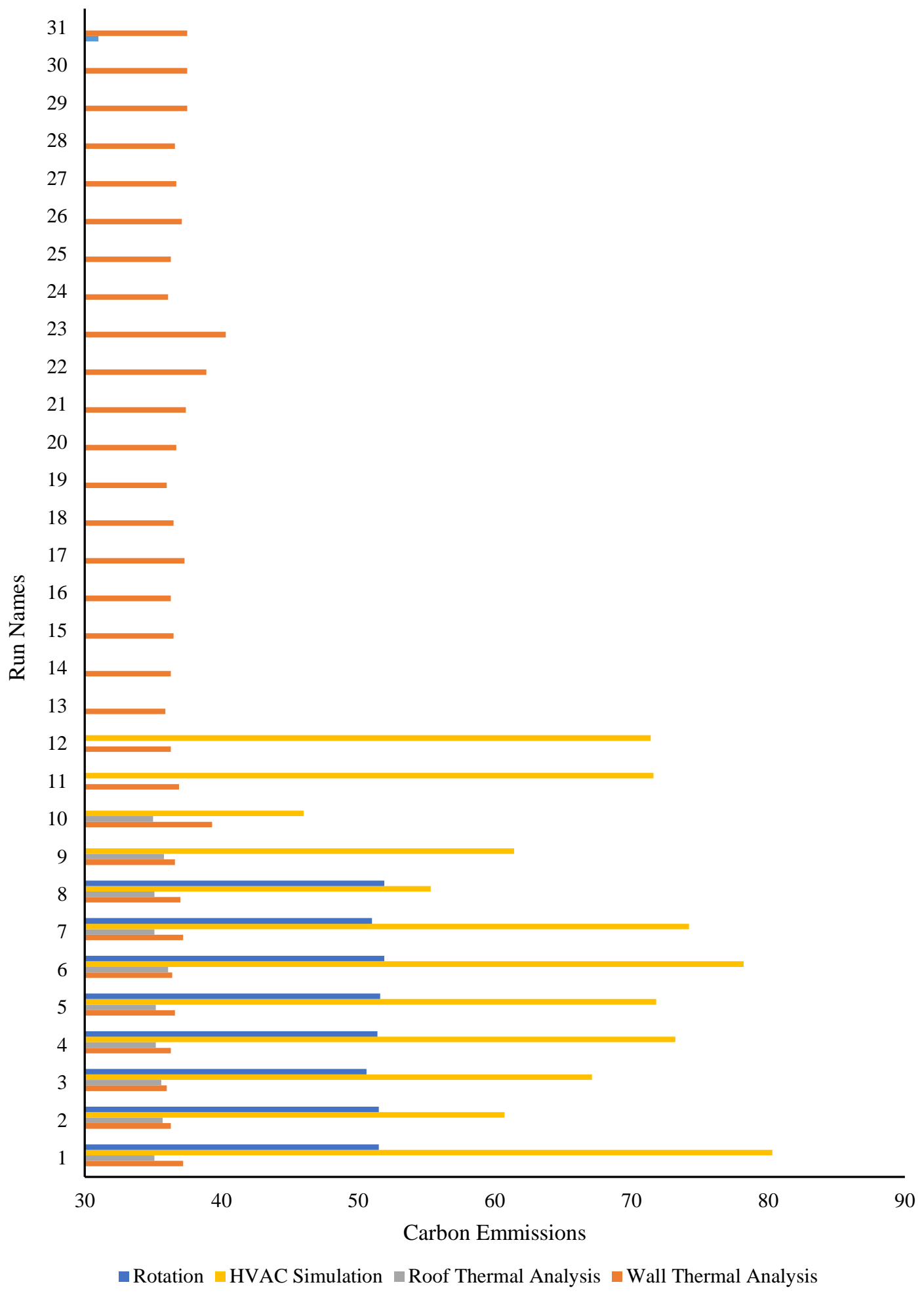

Fig. 15. Annual Carbon emissions for different combinations 
Comparison of roof pattern analysis: After analyzing 10 Roof combination simulation results, Roof 10 caused minimum life cycle cost (\$128272), annual energy cost (\$9418), and carbon emission (35 tons). Figs. 13-15 also show minimum life cycle cost, annual energy cost and carbon emission for Roof 10. Maximum value is represented by Roof 6 combination. Roof 10 combination consists of 6 inch concrete +2 inch foil faced glass fiber.

Comparison of building orientation analysis: After analyzing 8 orientation combination simulation results, Rotation 3 causes minimum life cycle cost $(\$ 126,110)$, annual energy cost $(\$ 9,259)$, and carbon emission (51.0 tons). Figs. 13-15 also show minimum life cycle cost, annual energy cost and carbon emission for Rotation 3. Maximum value is represented by Rotation 6 combination. The whole building rotates 90 degree from its default project north in Rotation 3 combination.

Comparison of HVAC simulation: Most of the energy in any building is consumed by HVAC system. After analyzing 12 HVAC combination simulation results, HVAC 10 caused minimum life cycle cost (\$156772), annual energy cost (\$11510), and carbon emission (46 tons). Figs. 13-15 also show minimum life cycle cost, annual energy cost and carbon emission for HVAC 10. Maximum value was represented by HVAC 7 combination. HVAC 10 combination is made of underfloor air distribution system which is the best energy efficient HVAC system among twelve HVAC systems.

Calculation of renewable energy production potentiality of BIPV system: BIPV system can be used as building element as window, window shading, balcony and anywhere building exterior part. It is very essential to estimate the possibility of PV energy production using BIPV as a building elements. In this study solar photovoltaic panels were mounted on building elements representing in Fig. 12 with blue marking areas. Roof mounted PV as well as extra transparent PV panels were installed on window glass, balcony glass railing and stair head room glass wall will meet total energy requirement of the prototype residential building.
Autodesk Insight 360 estimated the potentiality of PV energy of prototype building. Fig. 16 has shown the annual PV production $45560 \mathrm{kWh}$ from roof mounted panel estimating by Insight 360 . Likewise after selecting the window, balcony railing, stair headroom glass and roof, total PV production potentiality of BIPV system on prototype building is about $122800 \mathrm{kWh} /$ year. Requirement of energy annually for prototype building is $86267 \mathrm{kWh}$. The prototype building has potentiality to produce more energy than it requires to consume. Per year it can sell 36533kWh fresh renewable energy to the supply grid. The potentiality of BIPV was also calculated by theoretical means and necessary calculations and assumptions are given below

Global formula [36, 37] for PV energy calculation:

$\mathrm{E}=\mathrm{A} * \mathrm{r} * \mathrm{H} * \mathrm{PR}$

$\mathrm{E}=$ Energy $\quad(\mathrm{kWh})$

$\mathrm{A}=$ Total solar panel Area $\left(\mathrm{m}^{2}\right)$

$r=$ solar panel yield (\%) (Assume 15\%)

$\mathrm{H}=$ Annual average irradiation on tilted panels (shadings not included)*

$\mathrm{PR}=$ Performance ratio, coefficient for losses (range between 0.9 and 0.5 , default value $=0.85$ )

The project location was in Khulna, Bangladesh. Average solar irradiation rate of Bangladesh is $4.5-4.8 \mathrm{kWh} / \mathrm{m} 2$ daily \& 1680 $\mathrm{kWh} / \mathrm{m} 2$ per annum [38]. By installing photovoltaic panel on building roof, windows, balcony railing and stair headroom as representing Figure 12, the prototype building was able to produce 110600 kWh electricity annually. PV production result varies around $11 \%$ between Insight 360 and theoretical means.

Finally this study validated the simulation results through a case study application of a real project. The whole building energy simulation results obtained by green building studio was validated by comparing with measured data for an actual building [39]. In this study, energy simulations results were validated by comparing actual electricity consumption cost of Janata Bank, KUET, Khulna, Bangladesh against electricity cost resulted from Green Building Studio. 

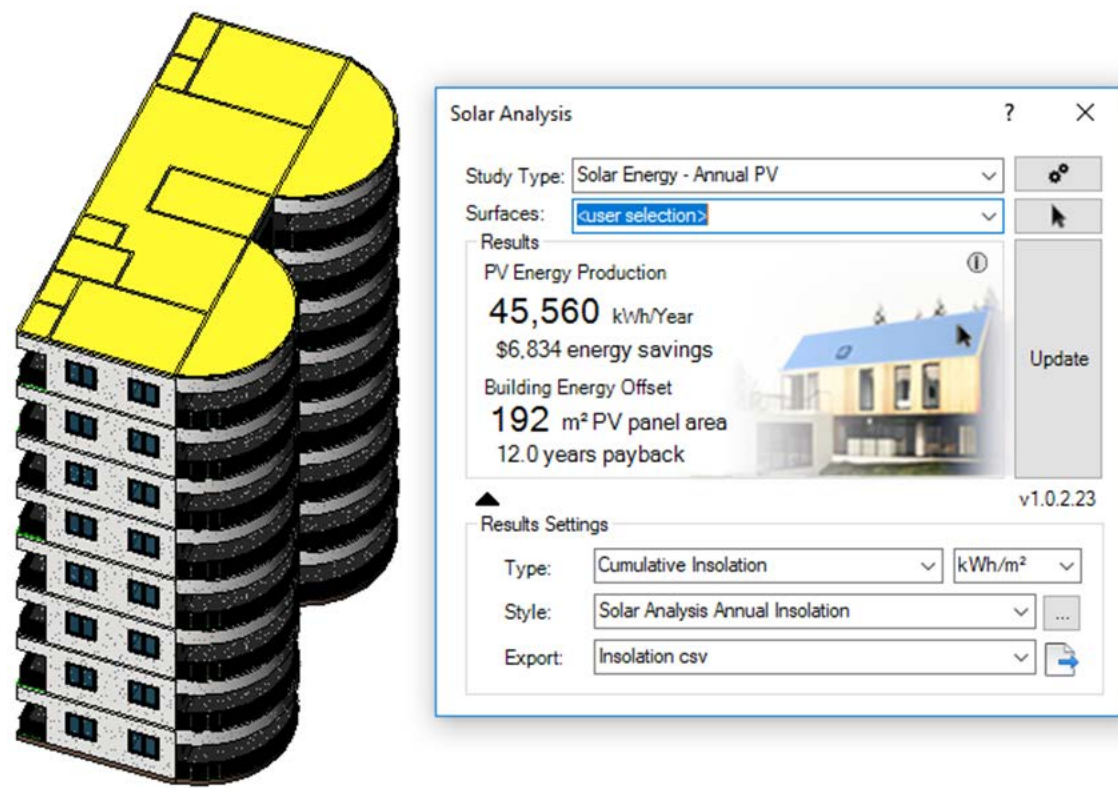

Fig. 16. Roof mounted PV production estimation using Autodesk Insight 360

F.H. Abanda and L. Byers validated their energy simulation results by comparing the computational data with real energy bills [14]. Real energy bill is often called true data \& comparison with real bill is a strong validation process [40].

Due to performing the validation, actual electricity cost per month of the Janata Bank Building was compared with the electricity cost per month that found from the Green Building Studio (GBS) results. Janata Bank building serves as office building. This office building was developed in Revit considering its real condition and simulated by Green Building Studio. This building is located at KUET in Khulna city of Bangladesh. All the information about electricity cost per month of the building was collected from the Janata bank information desk. There average electricity cost per month is about 15131 Taka (TK Bangladeshi currency) of the month of May to September year of 2018. From the GBS result sheet it was found that monthly $2703 \mathrm{kWh}$ electricity was consumed on average of the month May to September. This amount was multiplied with 5.50 TK (cost per KWh) to have electricity cost per month. The average electricity cost according to GBS result is about 14866 Taka per month. The variation is about
$2 \%$ from the actual electricity cost to GBS electricity cost per month. The accepted range of variation between computer simulation results and real measured data is about $+/-15 \%$ [41]

\section{Conclusions}

Design phase is a very critical time to take appropriate decisions considering various factors for developing NZEB. There are lots of passive technology options for building such as thermal insulation, window-to-wall ratio, orientation, natural ventilation and shading device. Architect/designer needs to choose appropriate passive options at preconstruction stage for designing a NZEB. BIM technology has the emerging impact for evaluating these passive options. This study analyzed two passive technologies like building envelope materials and orientation for developing NZEB at design phase using BIM. It also assessed the potentiality of BIPV system on prototype residential project. About 61 combinations were created using building envelope materials and orientations for evaluation to select the best energy efficient options. HVAC 10, Wall 13, Roof 10 and Rotation 3 are the best energy efficient combinations among 61 passive options 
because these four combinations showed lower life cycle cost, annual energy cost and annual carbon emission than other passive combinations. Wall 13 combination consists of light weight concrete, fiberglass and plastic board. Roof 10 combination is made of concrete and foil faced glass fiber. Light weight concrete with some insulations and foil faced glass fiber as wall and roof insulation respectively will be the best energy efficient options for prototype residential building. Rotation 3 combination was selected for building orientations and rotated the prototype building 90 degree anticlockwise from its project north direction. It was estimated that annual energy consumption of the prototype residential building was about 86267 $\mathrm{kWh}$ after incorporating the best passive options. Developing an energy efficient building is not enough, a building still requires energy to run all facilities. Renewable energy another elements of NZEB generally used as source of energy for running essential facilities. This study assessed the potentiality of renewable energy production of BIPV renewable energy system of that prototype residential building. Autodesk Insight 360 calculated that the prototype building can generate 122800 kWh energy annually using its BIPV system. Per year it can provide 36533kWh fresh renewable energy to the supply grid. Evaluation of passive technologies and potentiality of BIPV using $\mathrm{BIM}$ at preconstruction stage guides the architect/designer for designing NZEB. Architect/designer may find this study helpful at initial stage of any NZEB project to make appropriate decisions on building envelope, orientation and installation system of BIPV system. Net zero energy building (NZEB) reduces conventional energy requirement and carbon emission of any building at zero level. It ensures a safer, healthier and greener environment for our future generation.

\section{Limitations and further study}

Building energy consumptions depends on many factors like building envelope, orientation, glazing types, window wall ratio, building system, natural ventilation, exterior conditions and behavior of inhabitants but in this study only building envelope and orientation was considered for analysis with the help of BIM. Feasibility study was not done for wall and roof combination considering the mechanical properties and costing. For calculating the potentiality of PV production some issues were not considered like tilt angle of the panel, facing, visiting area and sun radiation intensity during different time period of a day. This study was only focused on two important passive solutions and showed how BIM can be utilized at design phase for decision making purposes. Further study can be done considering the factors stated above.

\section{Declaration of conflicting interests}

The author(s) declared no potential conflicts of interest with respect to the research, authorship, and/or publication of this article.

\section{References}

[1] Kim H, Stumpf A, Kim W (2011). Analysis of an energy efficient building design through data mining approach. Automation in Construction 20(1):37-43.

[2] Marszal AJ, Heiselberg P, Bourrelle JS, Musall E, Voss K, Sartori I, Napolitano A (2011). Zero Energy Building-A review of definitions and calculation methodologies. Energy and Buildings 43(4):971-979.

[3] Torcellini P, Pless S, Deru M, Crawley D. Zero energy buildings: A critical look at the definition. ACEEE Summer Study on Energy Efficiency in Buildings, 2006, CA, US.

[4] Marszal AJ, Heiselberg P (2011). Life cycle cost analysis of a multi-storey residential net zero energy building in Denmark. Energy 36(9):56005609.

[5] Guan X, Xu Z, Jia QS (2010). Energy-efficient buildings facilitated by microgrid. IEEE Transactions on Smart Grid 1(3):243-252.

[6] Feist W, Schnieders J, Dorer V, Haas A (2005). Reinventing air heating: Convenient and comfortable within the frame of the Passive House concept. Energy and Buildings 37(11):1186-1203.

[7] Albatayneh A, Alterman D, Page A, Moghtaderi B (2016). Assessment of the thermal performance of complete buildings using adaptive thermal comfort. 
Procedia-Social and Behavioral Sciences 216:655661.

[8] Cheung CK, Luther M, Fuller R. Low energy strategies for high-rise apartments in Hong Kong. in Modern practice of architectural science: from pedagogy to andragogy? 36th Conference of the Australian and New Zealand Architectural Science Association, 2002, Geelong.

[9] Cheung CK, Fuller RJ, Luther MB (2005). Energyefficient envelope design for high-rise apartments. Energy and Buildings 37(1):37-48.

[10] Sozer H (2010). Improving energy efficiency through the design of the building envelope. Building and Environment 45(12):2581-2593.

[11] Kumar S, Ambassador EE. Benchmarking Energy Use in Buildings and Cleanrooms. Bangalore: ISA Vision Summit, 2011.

[12] Morrissey J, Moore T, Horne RE (2011). Affordable passive solar design in a temperate climate: An experiment in residential building orientation. Renewable Energy 36(2):568-577.

[13] Xu X, Huajing S, Ji Y, Xu P. Energy consumption simulation of the prototypical building for optimizing the orientation of building model in the simulated environment. Asim2012, 2012, Shanghai, China.

[14] Abanda F, Byers L (2016). An investigation of the impact of building orientation on energy consumption in a domestic building using emerging BIM. Energy 97:517-527.

[15] Al-Tamimi N. Impact of building envelope modifications on the thermal performance of glazed high-rise residential buildings in the tropics. Malaysia: University Science Malaysia, 2011.

[16] Meral ME, Dincer F (2011). A review of the factors affecting operation and efficiency of photovoltaic based electricity generation systems. Renewable and Sustainable Energy Reviews 15(5):2176-2184.

[17] Al-Homoud MS (2005). Performance characteristics and practical applications of common building thermal insulation materials. Building and Environment 40(3):353-366.

[18] Koç S, Kalfa SM (2019). The effects of atrium on energy performances of office buildings according to Turkish climate regions. Journal of Construction Engineering, Management \& Innovation 2(3):144156.

[19] Jelle BP (2011). Traditional, state-of-the-art and future thermal building insulation materials and solutions-Properties, requirements and possibilities. Energy and Buildings 43(10):25492563.

[20] Aditya L, Mahlia TMI, Rismanchi B, Ng HM, Hasan MH, Metselaar HSC, Muraza O, Aditiya HB (2017). A review on insulation materials for energy conservation in buildings. Renewable and Sustainable Energy Reviews 73:1352-1365.

[21] Canım DS, Aydın Ö (2019). Energy performance evaluation of energy performance calculation method in buildings (Bep-Tr1). Journal of Construction Engineering, Management \& Innovation 2(1):18-29.

[22] Sadineni SB, Madala S, Boehm RF (2011). Passive building energy savings: A review of building envelope components. Renewable and Sustainable Energy Reviews 15(8):3617-3631.

[23] (eurima), E.I.M.A. About Mineral wool 2018; Available from: https://www.eurima.org/aboutmineral-wool.html.

[24] GreenSpec. Insulation materials and their thermal properties. 2019; Available from: http://www.greenspec.co.uk/buildingdesign/insulation-materials-thermal-properties/.

[25] Zmeškal O, Nežádal M, Lapčík L. Thermal conductivity of glass wool fiber. Institute of Physical and Applied Chemistry, Faculty of Chemistry, Brno University of Technology, Brno, Czech Republic.[Online]. Available: http://www. tpl. fpv. ukf. sk/engl_vers/... gs/zmeskal. pdf.[Accessed 14 Decemeber 2014], 2002.

[26] Edge E. Insulation materilas thermal conductivity chart. Copyright 2000-2019; Available from: https://www.engineersedge.com/heat_transfer/insu lation_material_thermal_conductivity_chart_131 70.htm.

[27] Tungkin Industry Co., L. Glass Wool Aluminum Foil Faced Pipe Insulation Thermal Conductivity 80 kg/m3. 2019; Available from: http://www.rockwool-insulation.com/sale-1524150-glass-woolaluminum-foil-faced-pipe-insulation-thermalconductivity-80-kg-m3.html.

[28] Toolbox, E. Thermal properties of common materials and gases. (2003); Available from: https:/www.engineeringtoolbox.com/thermalconductivity-d_429.html.

[29] Comfort, S.e.s. Thermal conductivity of cork insulation. 2019; Available from: https://www.nuclear-power.net/nuclearengineering/heat-transfer/heat-losses/insulationmaterials/thermal-conductivity-of-corkinsulation/. 
[30] Johansson E. Woodwool Slabs: Manufacture, Properties and Use. 1994: Lund University, Lund Centre for Habitat Studies.

[31] Boyle G. Renewable energy. Renewable Energy, by Edited by Godfrey Boyle, pp. 456. Oxford University Press, May 2004. ISBN-10: 0199261784. ISBN-13: 9780199261789, 2004: p. 456.

[32] Demirbas A (2009). Global renewable energy projections. Energy Sources Part B 4(2):212-224.

[33] Norton B, Eames PC, Mallick TK, Huang MJ, McCormack SJ, Mondol JD, Yohanis YG (2011). Enhancing the performance of building integrated photovoltaics. Solar Energy 85(8):1629-1664.

[34] Kalfa SM (2018). Building information modeling (BIM) systems and their applications in Turkey. Journal of Construction Engineering, Management \& Innovation 1(1):55-66.

[35] Mittal ML, Sharma C, Singh R. Estimates of emissions from coal fired thermal power plants in India. International Emission Inventory Conference, 2012.

[36] Software.com, P.; Available from: https://photovoltaic-software.com/principleressources/how-calculate-solar-energy-power-pvsystems.

[37] Carl C., Calculating solar photovoltaic potential on residential rooftops in Kailua Kona, Hawaii. MSc Thesis, University of Southern California, 2014.

[38] Sarkar MNI (2016). Estimation of solar radiation from cloud cover data of Bangladesh. Renewables: Wind, Water, and Solar 3(1):11.

[39] Ryan EM, Sanquist TF (2012). Validation of building energy modeling tools under idealized and realistic conditions. Energy and Buildings 47:375382.

[40] Jensen SØ (1995). Validation of building energy simulation programs: a methodology. Energy and Buildings 22(2):133-144.

[41] Reeves T, Olbina S, Issa R. Validation of building energy modeling tools: ecotect ${ }^{\mathrm{TM}}$, green building studio $^{\mathrm{TM}}$ and IES $<\mathrm{VE}>\mathrm{TM}$. in Proceedings of the Winter Simulation Conference. 2012. Winter Simulation Conference. 